\title{
Family Experience In Supporting Exclusive Breastfeeding In Surabaya
}

\author{
Sylvia Dwi Wahyuni, Ni Ketut Alit Armini, Naomi Sriwijayanti \\ \{sylvia.dwiwahyuni@fkp.unair.ac.id, nk.alita@fkp.unair.ac.id, nsriwijayanti@yahoo.com\}
}

Faculty of Nursing, Universitas Airlangga, Kampus C Mulyorejo Surabaya, Indonesia

\begin{abstract}
Word Health Organization recommends to exclusively breastfeed for the first six months old baby and continue until the age of two years. However, the coverage of exclusive breastfeeding still low. The study aims to explore family experiences in support of exclusive breastfeeding. This was a qualitative research with phenomenology study. Participants were families who had children at least one year old of age. Twelve participants were included. There were 8 themes to describe the research objective: 1) The characteristics of mothers and families, 2) Forms of family support, 3) Family functions, 4) Prevailing cultural forms, 5) Family stress, 6) Environment factors that affect exclusive breastfeeding, 7) Family experiences during exclusive breastfeeding. Stressor in the family included economic factors, infants, and mothers were considered. This results can be used by health workers to perform interventions on the family to increase exclusive breastfeeding coverage.
\end{abstract}

Keywords: exclusive breastfeeding, family experience, support

\section{Introduction}

Exclusive breastfeeding is feeding babies for six months without additional food and other drinks [1] The World Health Organization (WHO) recommends that mothers provide exclusive breastfeeding for the first six months and continue until the age of two years [2].

The benefits of breastfeeding increase with exclusive breastfeeding. Babies are protected from gastrointestinal infections, strengthen mother and child relationships, and increase intelligence. The benefits of breastfeeding that can be felt by the mother is to lose weight during pregnancy, reduce the risk of breast cancer, the mother can save household expenses, affect the inner relationship between mother and child, exclusive breastfeeding will increase the amount of antibodies in the mother's blood circulation so that it can reduce the risk of infection after giving birth [3]. However, many mothers do not give exclusive breastfeeding to their babies. 
One of the factors that influence the success of exclusive breastfeeding is the support of the family. Families can be one obstacle in giving exclusive breastfeeding because they feel sorry for babies who are considered still hungry or other reasons so that babies were given formula milk [4]. According to Ramona T. Mercer, there are several factors that affect a woman in achieving a role as a mother. Exclusive breastfeeding is one of the achievements of a woman in carrying out her role as a mother. In addition to the support given by the family, the family experience felt during exclusive breastfeeding will influence the mother's behavior in the future in breastfeeding. But until now the family experience in supporting exclusive breastfeeding in the working area of the Mulyorejo Public Health Center in Surabaya has not yet been explained.

Data from the Indonesian Health Profile in 2016 showed that the coverage of exclusive breastfeeding for infants 0-6 months in Indonesia was 29,5\%[5]. Meanwhile, the coverage of exclusive breastfeeding in East Java in 2016 was 31.3\%[6], while for Surabaya was $64.99 \%[7]$. Exclusive breastfeeding in Mulyorejo sub-district amounted to 70.34\% [8] Although the percentage was quite good, Mulyorejo sub-district did not meet the national ASI exclusive target by the Ministry of Health which issued Decree of the Minister of Health No. 450 / Menkes / SK / IV / 2004 concerning exclusive breastfeeding to infants as large as $80 \%$. Preliminary study conducted on July 10, 2017 by interviewing 3 families in the work area of the Mulyorejo health center, where 2 out of 3 families did not provide exclusive breastfeeding. The reason that is often expressed by mothers is that there is little milk production so that mothers give formula milk. Another cause was the lack of information and material support from families.

Research shows that low family support will prevent mothers from exclusively breastfeeding[9]. The intended support was informational support where families have low knowledge about exclusive breastfeeding. Developing cultural factors will also affect the family support process. The culture that develops in the community is the provision of early complementary food. it can cause gastrointestinal obstruction thus causing death.

The coverage of exclusive breastfeeding in Mulyorejo is quite good, but it still does not meet the target set by the government, so further research is needed to study family experience in exclusively breastfeeding. Researchers use qualitative research methods because none of the previous research has used a qualitative approach to explore in-depth information so data variations can appear.

\section{Method}

This study used a qualitative method with the type of phenomenology, which is a type of qualitative research that looks closely at individual interpretations of its experiences.

Sampling used snowball sampling, a method for identifying, selecting and taking samples in a continuous network or relationship. The sample of 9 families from 3 villages in Mulyorejo sub-district was 12 participants. The data taken from participants who had 
characteristics that determined by the researcher. Prospective participants were obtained from data from the Mulyorejo Health Center.

The sample used in this study met the inclusion criteria as follows: 1). Family with nuclear family or extended family consisting of father, mother, child and other family members (grandfather, grandmother, uncle, aunt), 2). Participants were located in the work area of the Mulyorejo health center, and 3). Having children with a minimum age of 1 year.

The Data collection tools used voice, interview guidelines, and field notes. This study used the epoche concept which means it was "delaying the decision" or "emptying yourself of certain beliefs". The interview was conducted around 60-90 minutes.

Data analysis was carried out with phenomenology method that developed by Colaizzi (1978) [10]. According to Colaizzi, data analysis was carried out in eight stages: 1) Gather participant data about participants' life experiences, 2) Read the entire description of the participant's statement, 3) Choose a significant statement, 4) Identify the meaning of each significant statement, 5) Grouping each meaning into the theme, 6) Write a profound picture, 7) Validating profound statements to participants, and 8) Combining the results of the analysis with validation data into the form of a deep final description.

This research has been conducted ethically feasibility test at the Airlangga University Faculty of Nursing Health Research Ethics Commission (KEPK) with 488-KEPK certificate number dated August 15, 2017.

\section{Result}

Education of 6 participants was high school, two participants have junior high school education, and other participants have a bachelor's degree. Participant work varies from private employees, entrepreneurs, industry, and housewives. The average income of participants was below the Surabaya Regional Minimum Wage (UMR) and three participants with income above the UMR.

The results of data analysis obtained 8 themes, 21 sub-themes, and 25 categories.

The form of family support was illustrated by one theme, namely a positive attitude, with three sub-themes, namely emotional support, real support, and informational support. The following was a detailed analysis of the form of family support theme:

\section{First Theme : positive attitude}

Family support in exclusive breastfeeding was focused on how family members provide support to mothers to choose exclusive breastfeeding. Family support in exclusive 
breastfeeding was focused on how family members provide support to mothers to choose exclusive breastfeeding.

"my husband gives enthusiasm..." (P11)

“give encouragement to breastfeed." (P10)

"people say that the child enters the age of two then stops breastfeeding, but my child if left behind to trade only wants to drink one bottle of milk. So, my husband asked me to continue breastfeeding." (P5)

In the sub-theme of real support, there was one participant who said that giving support in financial form.

"giving lots of money to shop." (P4)

In the sub-theme of real support with service categories, there were three participants who said they were assisted by mother, father-in-law, and husband while giving breastmilk.

"sometimes when I breastfeed in the morning, my husband helps cook rice or other work and makes a drink for the first child (smile)." (P2)

"my mother in-laws cook food that was believed to increase breastmilk production." (P 12)

"mother helps take care my child and if the child wants to breastfeed than she gives to me." (P9)

There was a category giving advice on informational support expressed by two participants.

"Mother advised me to eat lots of vegetables." (P 6)

"husband and mother-in-law suggested giving breastmilk." (P 7)

\section{Second Theme: Nutrition}

Providing nutrition for children in the form of mother's milk, formula milk, and early supplementary feeding .

“drink breastmilk until now.” (P 5)

“ my three children consume breastmilk.” (P7)

"she drinks breastmilk until 1 year and 3 months, after that she drinks bottle milk." (P 9) 
"first, I breastfeed my child, then I stayed in Malaysia, it was 9 years old, so my child drank formula milk "(P 11)

"breast milk production decreases when the child was one year old so I add formula milk.” (P 3)

"stop drinking breast milk since the age of 3 months." (P 12)

"full formula milk." (P6)

"Formula milk." (P 8)

"baby porridge was given when the baby was five months old." (P6)

\section{Third Theme: Prevailing Culture}

The results of the study show a habitual theme that was influential with two subthemes namely taboo and advice.

"my mather-in-law forbade me to eat fish after giving birth to my first child.” (P 2)

"if in front of them (mother) I didn't dare to eat food restrictions but if they didn't, I eat as I like." (P12)

In the recommended sub-theme, there were 3 participants who said that they did not believe in the myth of abstinence from food.

"homemade herbs, like turmeric, honey turmeric from spice leaves." (P 3)

"doctors forbid to restrict eating vegetables only." (P 9)

"my mother-in-law gave me vegetables to eat during breastfeeding." (P 12)

\section{Fourth Theme: Family Stressor}

The results of stressor form analysis in the family describe one theme: source of the stressor with three sub-themes, namely economic barriers, infant behavior, and motherhood. Economic sub-themes have insufficient categories. In the baby's problem, it has the category refuse to suckle. In the mother's problem sub-theme, there are two categories: breast milk comes out slightly and the anatomical shape of the breast.

"we feel economic barriers.....enough or not we try enough." (P 7)

"at that time my child did not want to suckle." (P8)

"he didn't want to drink breast milk." (P6) 
"My breastmilk was not too much and I also have trouble eating a lot." (P2)

"My breastmilk was dripping slowly." (P 9)

"my nipples were flat so the baby difficult to feed than cry." (P 12)

\section{Fifth Theme: Environmental Barriers}

An open environment was an obstacle for some mothers to breastfeed their babies. This was stated in the interview quote below:

"When I, baby, and my husband walked to the mall we looked for a quiet place to breastfeed or usually when It was crowded I closed using my cloth while breastfeeding." (P 1)

"if I go and invite a baby I still give brestmik but I close it because I am embarrassed if there are many people." (P 2)

"usually when I go to take my baby I also bring formula milk because I am embarrassed if I breastfeed in a public area." (P 9)

"if I go by train I look for a lactation room at the station so I can continue to breastfeed my baby ."(P 3)

"I trade and bring my child. I breastfeed behind a cart so people don't see it." (P5)

\section{Sixth Theme: Mother's Role}

The following interview excerpts show the feelings felt by mothers regarding their role in breastfeeding.

"I am happy to be able to breastfeed my child." (P9)

"I am grateful to be able to breastfeed my child. this is part of my struggle as a mother." (P2)

"I am happy and proud to be able to breastfeed my child.”(P3)

"I regret not being able to give ASI to my child. maybe if I have another child I will use an extra nipple so I can help me breastfeed." (P12)

"I really regret not being able to give breastmilk to my child." (P6) 


\section{Seventh Theme: impact for family}

quote below:

Reasons for breastfeeding give the impact for family This was stated in the interview

“Thank God, my child doesn't get sick easily. so, more economical too.” (P 7)

"Reduce family expenses.” (P8)

"Breastfeeding can be more efficient than giving formula milk." (P2)

\section{Eighth Theme: Benefits for Babies}

This theme has two sub-themes, namely: immunity and development. This was stated in the interview quote below:

"My child was not fussy,healthy, and active." (P5)

"My child's development was fast, by the age of 11 months it was already running." (P11)

"Her child was more cheerful, motoric was fast, and her development was fast." (P6)

\section{Discussion}

A positive attitude is a tangible manifestation of a mental atmosphere that pays attention to positive things, the atmosphere of the soul prioritizes creative activities rather than tedious activities. The support felt by participants was in accordance with family support according to Friedman. Family support expressed by Friedmen 1998 [11] were four family support, including: 1) Support for hope, including help for individuals to understand the incidence of depression, provide positive expression. 2) Real support, including providing physical support such as service, financial, and material (instrumental support) , 3) Information support, providing solutions, advice, direction, advice, or feedback, 4) Emotional support, giving the individual a feeling of comfort, feeling loved, help in the form of enthusiasm. This is in line with research by Kris Yuet Wan Lok et al, the support of husbands and other family members can maximize mothers in providing exclusive breastfeeding [12]. The results of the study by Joel Negin et al. (2016) explain that breastfeeding rates were influenced by several factors, one of which was the older generation. The older generation are baby grandmothers, both parents of mothers and fathers. The attitude or experience of the older generation has a significant positive impact during breastfeeding when the baby's grandmother has a breastfeeding experience so it was more likely to encourage mothers to breastfeed exclusively [13].

One of the functions of the family is health maintenance that aims to maintain a healthy state. Breast milk is an ideal food for babies. Breastmilk is safe, clean, environmental 
friendly and contains antibodies that protect children against many common diseases[14]. Breastfeeding can help mothers recover after labor. Breastfeeding during the first few days makes the uterus contract quickly and slow the bleeding [15]. It was in accordance with the opinion of Roesli (2005) on the seven benefits of breastfeeding for babies. Benefits of the first three are as follows: 1) As a single food to satisfy all the growing needs of babies up to age 6 months, 2) Improve endurance because it contains some anti immunity so it will be less sick, 3) Protecting children from an allergy attack. While the benefits of breastfeeding for mothers were found in this study is the health category. While the benefits to the mother in accordance with the third point, namely: 3 ) Decrease the risk of premenopausal breast cancer, especially if the first lactation occurs before the age of 20 years and breastfeed at least 6 months. This is also confirmed by Roesli (2007) that breastfeeding at least up to 6 months reduce the likelihood of a mother suffering from breast cancer, uterine cancer, ovarian cancer. Protection against breast cancer in accordance with the length of breastfeeding but some participants in this study gave exclusive breastfeeding and some did not.

All participants came from the Javanese tribe that one of the Javanese beliefs was abstinence from food. Participants said that family members forbade eating marine fish because they were thought to slow the healing of wounds after childbirth and make breast milk become fishy. This was contrary to Angga's research, the quantity of food for breastfeeding mothers is greater than pregnant mother, but the quality remains the same. Breastfeeding mothers are expected to consume nutritious foods without restrictions. Nutritional needs during breastfeeding mothers such as carbohydrates which increase by 65 grams / day or equivalent to $11 / 2$ servings of rice. Breastfeeding mothers need an additional 17 grams of protein that can be obtained from consumption of meat, fish, eggs to increase milk production. Fat serves as a source of energy and plays a role in the production of breast milk and carries fat-soluble vitamins in breastmilk. Breastfeeding mothers need more vitamins and minerals. Vitamin levels in breast milk are strongly influenced by vitamins that mothers eat. Vitamins that are important in breastfeeding are vitamins B1, B6, B2, B12, vitamin A, iodine and selenium[16][17].

One of the stressors experienced by participants was the condition of the flat nipples or drowning nipples so that the baby has difficulty when starting to suckle $t$ hcry so that the baby refuses to suckle on the mother's breast then mother became confuse. Finally, finally, babies didn't get breast milk It was suitable with Diana (2007) explains that the condition of the mother's breast has a role in the success of breastfeeding such as nipples sinking, horizontal, or too large nipples can interfere with the process of breastfeeding. Breast milk production is more determined by nutritional factors, suction factors, and emotional factors[18].

The lack of lactation room facilities in public places was also a barrier to breastfeeding. Some respondents chose to close the baby's head while breastfeeding in a 
public place. Some other mothers decide to bring formula milk when they go out of the house and visit crowded places.

\section{Conclusion}

Family support is needed for breastfeeding mothers to achieve their role. Mothers who get family support will find it easier to face obstacles in breastfeeding The existence of obstacles in the family during breastfeeding were an insufficient economic factor, babies who are reluctant to suckle, insufficient breast milk, and the anatomical shape of the breast. Mothers who succeed in exclusive breastfeeding feel happy, proud, and carry out their roles as mothers after going through various obstacles during the breastfeeding process.

\section{References}

[1] F. Ulil Albab, "Hubungan Promosi Susu Formula Dengan Pengambilan Keputusan Keluarga Dalam Pemberian Asi Eksklusif Di Wilayah Kerja Puskesmas Arjasa Kabupaten Jember,” Progr. Stud. Ilmu Keperawatan Univ. Jember, pp. 1-118, 2013.

[2] S. I. Nasution, N. I. Liputo, and Mahdawaty, "Artikel Penelitian Faktor-Faktor yang Berhubungan dengan Pola Pemberian ASI Eksklusif di Wilayah Kerja Puskesmas Bungus Tahun 2014,” J. Fak. Kedokt. Andalas, vol. 5, no. 3, pp. 635-639, 2016.

[3] D. L. Fahdila, Dr. Siti Rayhani; Ninditya, "Dampak dari Tidak Menyusui di Indonesia," $2016 . \quad$ [Online]. Available: http://www.idai.or.id/artikel/klinik/asi/dampak-dari-tidak-menyusui-di-indonesia.

[4] S. Rejeki, "Studi Fenomenologi: Pengalaman Menyusui Eksklusif Ibu Bekerja Di Wilayah Kendal Jawa Tengah,” Nurse Media J. Nurs., vol. 2, no. 1, pp. 1-13, 2010.

[5] Dinas Kesehatan Kabupaten Bangkalan, "Laporan Kasus Tuberkulosis di Bangkalan 2015-2016," Bangkalan, 2016.

[6] Kementerian Kesehatan RI, "Profil Kesehatan Indonesia 2017," Profil Kesehat. Indones. 2017, p. 100, 2018.

[7] D. K. P. K. Surabaya, "Profil Dinas Kesehatan Surabaya," Surabaya, 2015.

[8] B. P. S. K. Surabaya, "Laporan Kecamatan Mulyorejo dalam Angka," Surabaya, 2016.

[9] S. Kristianti and S. Pratamaningtyas, "Exclusive Breastfeeding Support from Family and Healthcare Provider," vol. 6, no. 4, pp. 36-40, 2017.

[10] C. T. Polit, D. F. \& Beck, Nursing Research, Generating and Assessing Evidence for Nursing Practice. Baltimore: Wolters Kluwer Health.

[11] Harnilawati, Konsep dan Proses Keperawatan Keluarga. Sulawesi Selatan: Pustaka As salam, 2013.

[12] K. Y. W. Lok, D. L. Bai, and M. Tarrant, "Family members' infant feeding preferences, maternal breastfeeding exposures and exclusive breastfeeding intentions," Midwifery, vol. 53, no. January, pp. 49-54, 2017.

[13] J. Negin, J. Coffman, P. Vizintin, and C. Raynes-Greenow, "The influence of 
grandmothers on breastfeeding rates: A systematic review," BMC Pregnancy Childbirth, vol. 16, no. 1, 2016.

[14] W. H. Organization, "Breastfeeding," 2018. [Online]. Available: https://www.who.int/nutrition/topics/exclusive_breastfeeding/en/.

[15] Bahiyatun, buku-ajar-asuhan-kebidanan-nifas-normal-2009_library-stikespekajangan-2014.pdf, 1st ed. Jakarta: EGC, 2009.

[16] Angga, "Manejemen Laktasi," 2016. [Online]. Available: http://gizi.fk.ub.ac.id/manajemen-laktasi.

[17] U. Roesli, Panduan Praktis Menyusui. Jakarta: Pustaka Bunda, Grup Puspa Swara, 2009.

[18] D. N. Afifah, "Faktor Yang Berperan Dalam Kegagalan Praktik Pemberian ASI Ekslusif (Studi Kualitatif di Kecamatan Tembalang, Kota Semarang Tahun 2007)

Factor Contributing To The Failure Of Exclusive Breastfeeding (Qualitative Study at Kecamatan Tembalang, Semarang 2007),” 2007. 